\title{
Editorial
}

\section{A New Publisher, A New Horizon}

\section{Uma Nova Editora, um Novo Horizonte}

\section{Dear colleagues}

With the year 2017 starting, GE-Portuguese Journal of Gastroenterology starts a new and ambitious collaboration with a new publisher: Karger Publishers.

In the past 4 years, GE-Portuguese Journal of Gastroenterology was published by Elsevier, the biggest publisher in the area of scientific publications. Thanks to an intensive work of the past and present editorial team, GE-Portuguese Journal of Gastroenterology achieved an international reputation. We developed changes in accordance with the highest ethical and editorial standards that led to indexation in Scopus, one of the largest abstract and citation databases of peer-reviewed literature, the SciELO Citation Index of Web of Science (Thomson Reuters), and the Directory of Open Access Journal (DOAJ). The number of submitted articles has increased significantly (more than 100 submitted articles in 2016), and reviewing/publishing times became in line with the most important and prominent journals in the area. Long story short: the quality of our journal has increased.

Of course, all of this could not have been possible without the incredible work that all of you, Portuguese gastroenterologists, have done by submitting high-quality review articles, editorials, and original articles as well as providing high-quality reviews of the submitted articles. For all of that we are really thankful!

At Elsevier, we were a small journal from a big publisher, and our needs and ambitions were not always fulfilled. We needed a publisher more dedicated to support us in achieving our goals. Our new publisher should commit to the following:

- enable a soft and rapid transition, keeping the actual quality of the journal and its indexations;

- preservation of an open access format;

- improvement of technical, ethical, and scientific aspects;

- active support for further indexations in important databases (e.g. PubMed and Web of Science);

- active and ambitious involvement to pursue the internationalization of the journal.

With Karger Publishers, we are confident that these goals will be reached. From all the publishers that we approached, we believe Karger Publishers is the best choice. Karger Publishers is an international and reputable publishing house with more than 125 years of experience in medical and scientific publishing. The Karger publication program comprises 50 new books per year, 100 peer-reviewed journals, and a growing number of open-access publications. Furthermore, it represents 7 international journals in gastroenterology and a renowned book series. These features make of Karger a big and international publisher but a company on a human scale. The promise of an individualized and professional support and consulting convinced us for cooperation.

Nevertheless, we have to remember that a good publisher is not a guarantee for a good journal. The quality of the published articles will say about the value of the journal.

We thus still count on you all to improve the quality of GE-Portuguese Journal of Gastroenterology, with a sight on a new horizon!

Pedro Pimentel-Nunes (editor-in-chief) José Cotter (director)

\section{KARGER}

E-Mail karger@karger.com www.karger.com/pjg
(C) 2016 Sociedade Portuguesa de Gastrenterologia Published by S. Karger AG, Basel

Karcer

Open access

This article is licensed under the Creative Commons AttributionNonCommercial-NoDerivatives 4.0 International License (CC BYNC-ND) (http://www.karger.com/Services/OpenAccessLicense). Usage and distribution for commercial purposes as well as any distribution of modified material requires written permission. 